\title{
Sensory Analysis of New Varieties of Citrus as a Complementary Strategy to the Brazilian Citriculture
}

\author{
D. B. A. Castro ${ }^{1}$, F. N. Maurício ${ }^{1}$, M. Cristofani-Yaly ${ }^{2}$, M. Bastianel², E. H. Schinor ${ }^{2} \&$ M. R. Verruma-Bernardi ${ }^{3}$ \\ ${ }^{1}$ Federal University of São Carlos, Center of Agricultural Sciences, Via Anhanguera, Km 174, Araras, São Paulo, \\ Brazil \\ ${ }^{2}$ Center APTA Citrus Sylvio Moreira, Agronomic Institute of Campinas, Via Anhanguera, Km 158, Cordeirópolis, \\ São Paulo, Brazil \\ ${ }^{3}$ Federal University of São Carlos, Center of Agricultural Sciences, Department of Agroindustrial Technology \\ and Social-Rural Economy, Via Anhanguera, Km 174, Araras, São Paulo, Brazil
}

Correspondence: D. B. A. Castro, University of Campinas, Center for Molecular Biology and Genetic Enginnering, Avenida Cândido Rondon, 400, Campinas, São Paulo, Brazil. CEP:13083875. Tel: 55-198-242-6025. E-mail: dan.castro@ig.com.br

Received: December 31, 2012 Accepted: February 19, 2013 Online Published: March 15, 2013

doi: $10.5539 /$ jas.v5n4p161

URL: http://dx.doi.org/10.5539/jas.v5n4p161

\begin{abstract}
In Brazil new varieties of citrus were selected along the years, but none sensory analysis is usually made to verify the acceptance as one of the bottleneck for fresh citrus juice industry and before the commercial release. We have evaluated the response of consumers $(n=62)$ for eight new hybrids of the crossing between sweet orange and mandarin in five sensory attributes and used analysis of variance Tukey's procedure (HSD) and internal preference mapping for the data processing. The results were compared in relation to their standard physical-chemical characteristics and with commercial varieties: Murcott tangor (Citrus sinensis (L.) Osbeck x Citrus reticulata Blanco), Pera sweet orange (Citrus sinensis (L.) Osbeck, Cravo mandarin (Citrus reticulata Blanco). Hybrids TM x LP 222 and TC x LP 5 are candidates to become variety and TM x LP 94 was chosen for new sensory analysis. Flavor featured as the most important parameter for orange juice and some hybrids with adequate physical-chemical parameters presented low acceptance, while others with inadequate parameters showed good acceptability, what suggests a new way to fruit selection.
\end{abstract}

Keywords: industry, ratio, orange, sensory analysis, consumer

\section{Introduction}

Brazil is the world's largest orange-producing and third of mandarins with planted areas around 817.3 and 53.2 thousand hectares, and production of 19.8 and 1.0 millions of tons in 2011, respectively (Food and Agriculture Organization - FAO, 2013). São Paulo State is the major orange producer with about 15.3 millions of tons in 2011, which represents $77 \%$ of the total production of Brazil (Brazilian Institute of Geography and Statistics - IBGE, 2011). Florida and São Paulo account for $81 \%$ of the world production of orange juice. The state of São Paulo alone is responsible for $53 \%$ of the total, however, because of phytosanitary reasons the cropped area has declined. In the last decade, 40 millions of plants in Brazil were eradicated due to plagues and diseases (Neves et al., 2010).

Traditionally, Pera sweet orange is the most notable variety consumed in Brazil with appropriate values of $11.8{ }^{\circ}$ Brix, $51 \%$ of juice yield, 12.5 for ratio, approximately $1.14 \mathrm{~g} / 100 \mathrm{~mL}$ of acidity, and variable mass of $145 \mathrm{~g}$ (Salibe, 2002; Pio, 2005; CEAGESP, 2009; Couto \& Canniatti-Brazaca, 2010). Another two important varieties are Murcott tangor and Cravo mandarin with adequate quality values established respectively: 12.6 and $10.8^{\circ}$ Brix, $48 \%$ of juice yield for both, 13.7 and 13.5 for ratio, acidity of $0.92 \mathrm{~g} / 100 \mathrm{~mL}$ and $0.8 \mathrm{~g} / 100 \mathrm{~mL}$ and middle-weight of $140 \mathrm{~g}$ and $135 \mathrm{~g}$ (Teófilo et al., 2001; Pio, 2005).

As Pera sweet orange as both Murcott tangor and Cravo mandarin can be susceptible in different degrees to several diseases thus, the actual researches in Brazil are focused on phytosanitary aspects and mainly on the pathosystems Citrus variegated chlorosis or CVC, Citrus leprosis virus, Huanglonnbing, Citrus sudden death, Citrus tristesa virus, Phytophthora Gummosis, Citrus canker, Citrus black spot and Alternaria brown spot. An approach is made by the Citrus Center APTA Sylvio Moreira genetic breeding programs, which searches for new varieties by 
obtaining hybrids from the cross-breedings between plants should have genetic variability and agronomic values as stress tolerance and physical-chemical quality. An example of cross-breedings is the one between the Pera sweet orange, which is CVC susceptible and resistant to Alternaria brown spot with Murcott tangor or Cravo mandarin, both resistant to CVC, and Murcott tangor susceptible to Alternaria brown spot (Oliveira et al., 2002; Bastianel et al., 2004; Souza et al., 2006; Machado, Cristofany-Yaly, \& Bastianel, 2011; Figueiredo et al., 2012; Pacheco et al., 2012).

Physical-chemical analyses have fundamental importance in food quality (Zenebon, 2008), but provides an incomplete profile. On the other hand, the responses given by consumers in sensory analysis are derived from the behavior (psychological characteristics) and stimuli (physical and chemical characteristics) that the product offers to them, which determine the sensations and interpretation of product properties (Rodas \& Torre, 2008).

Commonly, none sensory analyses of juice and fruit appearance are performed with the purpose to provide a better characterization of new hybrids or as a selection step for juice industries. According to Minim (2006), when considering whether a consumer likes or dislikes of a certain product, balanced acceptance tests are normally chosen, whereas these have the same number of negative and positive categories, equally spaced terms and discriminative and inquirer bias. She highlights hedonic scale as one of the most used, which consists in the consumer's expression for the product and an established rating easily understood and applied by the companies. After the sensory evaluation, analysis of variance (ANOVA) and Tukey's Honestly Significant Difference procedure (HSD) were used for the data treatment, even though these analyses considers that all of the consumers have the same behavior and that the average is correctly represented, not accounting for the consumers individuality and not indicating groups with similar preferences. An alternative is to analyze the data with multivariate statistic as an internal preference mapping. The internal preference maps considers one data matrix of the preference and the variable tested on the acceptance test, being represented on orthogonal positions on a graphic (Cardello \& Faria, 2000).

Considering the national importance of the citrus and that a few or none work has been done to complement the traditional methods of fruits selection performed by the Brazilian orange juice industries through sensory tests, we evaluated physical-chemical parameters and consumers' acceptability to sensory characteristics of citrus hybrids.

\section{Materials and Methods}

\subsection{Fruit Selection and Physical-Chemical Profile}

Healthy and mature fruits from the crossing between Murcott tangor (TM) with Pera sweet orange (LP) and from the crossing between Cravo mandarin (TC) with Pera sweet orange were harvested at the same day and field in Citrus Center Sylvio Moreira in June 2011, Cordeirópolis, São Paulo, Brazil, stored in the Federal University of São Carlos (UFSCar) and named according to the crossings and plant number on the field: TM $\times$ LP 247, 225, 222, 94, 13 and TC $\times$ LP 5, 103, 110 .

The physical-chemical analyses were carried at the Fruit Quality Laboratory of the Citrus Center Sylvio Moreira/Agronomic Institute which assembled the fruits characterization data of mass (g), juice yield in percentage (mass of juice per mass of fruit), acidity (Latado et al., 2008), total dissolved solutes or TDS ( ${ }^{\circ}$ Brix) and ratio ( ${ }^{\circ}$ Brix/acidity).

\subsection{Sensory Analysis}

One manual juicer extractor with filters was used for each fruit and no addition of any product to the juices, as sweetener or coloring, was used during the experiment. The juices were made just with pulps, on demand of the consumers and maintained at acclimatized room $\left(22-25^{\circ} \mathrm{C}\right)$ until were consumed. The fruits did not have injuries and were slightly varnished.

Panelists were female $(\mathrm{n}=28)$ and male $(\mathrm{n}=34)$ aged from 18 to 30 years old. The juices $(50 \mathrm{~mL})$ were dispensed into plastic cups, at $22-25^{\circ} \mathrm{C}$, numbered with 3 -digit codes, and were monadically presented to consumers in sensory booths under white light and evaluated in structured 9-point hedonic scale varying from 1 (extremely dislike) to 9 (extremely like) considering color, aroma, texture and flavor parameters of the juice, and overall appearance of the fruit. The study started the day after harvesting the fruits with two sessions daily, at 09:00 to 11:00 a.m. and 02:00 to 04:00 p.m. at the sensory analysis laboratory of UFSCar (four samples per each time).

The order of presentation was balanced and followed the complete block delineation design (MacFie et al., 1989). Judgers evaluated samples seated on student desks and received from the authors the instructions to proceed correctly with the test. To blank the mouth, a glass of fresh water was served between samples. Just after each taster drank a juice, the fruit of the same sample was presented to appearance evaluation, but no direct visual comparison of the samples was permitted. No talk that could interfere on the evaluation was allowed. 


\subsection{Statistical Analyses}

The dataset generated on the sensory evaluation were treated by analysis of variance (ANOVA) and Tukey's Honestly Significant Difference procedure (HSD) to check differences between hybrids $(p<0.05)$ using the statistical program SAS Software $9.1^{\mathbb{B}}$ (SAS, 2003) and considering eight samples and sixty-two judgers as causes of variation for each characteristic evaluated.

To obtain the internal preference maps, correlation matrices were made to each sensory characteristic followed by analysis of principal components (Borgognone, Bussi, \& Hough, 2001) with the FactoMineR package (a multivariate analysis tool) developed by Husson et al. (2007) for the software R 2.13.0 (R Development Core Team, 2011). Principal components analyses were performed based on the responses of consumers for each characteristic to allow best description and summarization of the sensory analysis.

\section{Results and Discussion}

Quality of fruits and their derivatives has a set of physical-chemical attributes as mass, juice yield, acidity, TDS, ratio and sensory characteristics that add worth as human food (Kader, 1999) thus, this linkage has been seen in the three commercial varieties of this study and could be compared with the hybrid fruits (Table 1).

Table 1. Physical-chemical analysis of hybrids of Murcott Tangor versus Pera Sweet Orange and Cravo Mandarin versus Pera Sweet Orange

\begin{tabular}{llllll}
\hline Hybrids & Mass $(\mathrm{g})$ & Juice Yield (\%) & Acidity* & TDS** & Ratio \\
\hline TM x LP 222 & 136.38 & 52.15 & 1.01 & 12.13 & 9.94 \\
TM x LP 94 & 175.50 & 38.05 & 0.80 & 7.23 & 8.95 \\
TM x LP 247 & 223.90 & 36.00 & 0.73 & 7.40 & 10.20 \\
TC x LP 110 & 126.00 & 42.90 & 1.03 & 10.90 & 10.60 \\
TM x LP 13 & 152.00 & 47.70 & 1.97 & 10.65 & 6.45 \\
TC x LP 103 & 121.40 & 57.66 & 1.32 & 10.54 & 8.10 \\
TC x LP 5 & 157.00 & 45.10 & 0.82 & 9.74 & 11.98 \\
TM x LP 225 & 196.17 & 38.30 & 2.39 & 10.63 & 4.63 \\
\hline
\end{tabular}

*Acidity expressed on $\mathrm{g} / 100 \mathrm{~mL}$. **TDS: Total dissolved solids expressed on ${ }^{\circ}$ Brix.

Although the hybrids are originated from two cross-breedings (TC x LP and TM x LP) that could lead to erroneous interpretations about the real number of samples used, it is important to highlight the genetically bias intrinsic on it. When dealing with cross-breedings, the segregation of genes due to the meiosis and specifically the recombination and linkage events produces different combinations of the genetic constitution (genotypes) (Griffths et al., 2008). This is the core that could lead us to treat them as different samples in the physical-chemical and sensory analysis. Therefore, the individuals could be alike because they come from the same progenitors and are present on the same environment, but the genotypes are responsible to turn them different from each other. This can be exemplified by the masses data that showed variable values for all hybrids, despite all similarity when it concerns progenitors and environment. In spite of values greater and lower than the commercial cultivars, consumers are not influenced firstly by mass (Teixeira et al., 2004; Rombaldi et al., 2007), what could not be used as the main bottleneck for the juice industries. In opposite to this, fruits with more juice in relation to their masses are completely desirable, so for juice yield, TC x LP 103 and TM x LP 222 showed superior amount of juice than Pera sweet orange (51\%), Murcott tangor and Cravo mandarin (48\%), and these factors feature them with a good characteristic for juice industries, while just hybrids TM x LP 94, TM x LP 225 and TM x LP 247 had lower juice yield than the Brazilian appropriated value of $40 \%$ for juice yield (MAPA 2000; Pio, 2005)

In respect of TDS, lower averages for TM x LP 94 and TM x LP 247 can be observed and, therefore, lower presence of sugars are observed in these hybrids, but the opposite was found on TM x LP 222, TC x LP 110, TM x LP 13, TC x LP 103, TC x LP 5 and TM x LP 225, which had similar averages in relation to the commercial cultivars. All hybrids were close to the acidity variation between $1.4 \mathrm{~g} / 100 \mathrm{~mL}$ and $0.8 \mathrm{~g} / 100 \mathrm{~mL}$, the minimum recommended for juice industry (Pio, 2005). High values as TM x LP 225 and TM x LP 13 can justify the presence of sour taste and the acidity can also indicate not mature fruits, whereas with the development this tends to decrease. 
The correct time for harvesting guarantees the quality of the fruit, being the harvest period the most difficult step faced by producers (Jayasena \& Cameron, 2008). In this study, we standardized all samples in the moment of harvest, choosing only the mature ones to the sensory analysis and in our physical-chemical database, the same proceedings were previously taken. An analysis of the relation between total dissolved solids and acidity (denominated ratio) is necessary and provides the maturation level of the fruit, its palatability (Pereira et al., 2006), in addition to the best quality of juice when this relation is perfect (Cancalon, 2003). This relation is the main criteria used by the juice industries as a filter to separate the good fruits from the poor ones and affects directly on consumers acceptance (Brandão et al., 2003; Jayasena \& Cameron, 2008). Only TM x LP 13 and TM x LP 225 were not adequate in relation to the ratio minimum parameters in Brazil (MAPA, 2000; MAPA, 2002), being the acidity too accentuated in comparison to the others hybrids, what confirms that both hybrids are not indicated to consumers.

Therefore, based on the relation to the minimum parameters in Brazil, industrial requirements for acidity and the similarity to Pera sweet orange, Murcott tangor and Cravo mandarin, the TM x LP 222, TC x LP 110, TC x LP 103 and TC x LP 5 were adequate hybrids with better, equal or similar characteristics than the others (MAPA, 2000; MAPA, 2002; Pio, 2005).

Physical-chemical and sensory analysis are tools to characterize food and beverage and generally these techniques are not carried together, although it is useful what they produce when they are combined (Carolyn, 2009). For a best selection, we proposed a complementary step through a sensory analysis.

Table 2 presents a matrix with color, aroma, flavor, texture, fruit, rejection indexes (consumer ratings $\leq 6$ ) and approval indexes (consumer ratings $\geq 7$ ). The indexes are based on flavor scores, whereas this is the main attribute of orange juice. The choice of consumer ratings $\geq 7$ for approval indexes corresponds to a consumer who regularly liked of a specific juice and would buy it with more probability than one who slightly liked it $(r a t e=6)$ or disliked it $($ rate $<6)$.

Table 2. Means of sensory attributes and acceptability scores of the juices and fruits

\begin{tabular}{lccccccc}
\hline Samples & Color & Aroma & Flavor & Texture & Fruit* & Approval index (\%) & Rejection index (\%) \\
\hline TC x LP 110 & $5.9^{\mathrm{a}}$ & $6.3^{\mathrm{ab}}$ & $4.0^{\mathrm{ab}}$ & $5.8^{\mathrm{ab}}$ & $5.8^{\mathrm{a}}$ & 22.6 & 77.4 \\
TC x LP 103 & $6.5^{\mathrm{ab}}$ & $6.4^{\mathrm{ab}}$ & $5.3^{\mathrm{cd}}$ & $6.2^{\mathrm{abc}}$ & $6.6^{\mathrm{ab}}$ & 40.3 & 59.7 \\
TM x LP 222 & $6.6^{\mathrm{abc}}$ & $7.2^{\mathrm{b}}$ & $7.6^{\mathrm{e}}$ & $7.5^{\mathrm{d}}$ & $6.6^{\mathrm{ab}}$ & 80.6 & 19.6 \\
TC x LP 5 & $6.8^{\mathrm{bc}}$ & $6.9^{\mathrm{ab}}$ & $6.4^{\mathrm{de}}$ & $6.5^{\mathrm{bcd}}$ & $7.2^{\mathrm{b}}$ & 58.1 & 41.9 \\
TM x LP 13 & $7.0^{\mathrm{bc}}$ & $6.6^{\mathrm{ab}}$ & $5.2^{\mathrm{c}}$ & $6.2^{\mathrm{ab}}$ & $7.4^{\mathrm{b}}$ & 37.1 & 62.9 \\
TM x LP 225 & $7.0^{\mathrm{bc}}$ & $6.1^{\mathrm{a}}$ & $3.1^{\mathrm{a}}$ & $5.3^{\mathrm{a}}$ & $7.0^{\mathrm{b}}$ & 4.8 & 95.2 \\
TM x LP 247 & $7.0^{\mathrm{bc}}$ & $6.3^{\mathrm{ab}}$ & $4.9^{\mathrm{bc}}$ & $5.9^{\mathrm{ab}}$ & $6.8^{\mathrm{b}}$ & 30.6 & 69.4 \\
TM x LP 94 & $7.4^{\mathrm{c}}$ & $6.9^{\mathrm{ab}}$ & $7.0^{\mathrm{e}}$ & $7.2^{\mathrm{cd}}$ & $6.8^{\mathrm{b}}$ & 71.0 & 29.0
\end{tabular}

Values with different superscript letters within the same column are significantly different by Tukey's test $(\mathrm{P} \leq 0.05)$. *Fruit overall appearance.

The HSD revealed a wide range of ratings and differences as expected in flavor, which is the main attribute in orange juice, also in texture and color. Volatiles compounds as limonene, $\alpha$-terpineol and $\beta$-pinene, and others, compose the aroma of orange juice (Plotto, 2004), however, the tasters were not trained to identify these substances, so the aroma attribute presented low range of rating and differences, what suggests not using it in affective tests, whereas it does not discriminate the consumers' acceptance, as well as for overall appearance, which can influence consumers (Teixeira et al., 2004; Rombaldi et al., 2007), however, because of the similarity of the samples in size and aspect, almost no differences were found. Complementary to the physical-chemical analysis, sensory analysis comprised the inadequacy of TM x LP 225, TM x LP 13 and TM x LP 247. TM x LP 225 obtained low scores in aroma, flavor and texture with the worse rejection index, proving to be not adequate to consumers, despite high scores in color and overall appearance. Differently of the physical-chemical adequacy, TC x LP 110 and TC x LP 103 had rejection indexes above 50\% and low scores mainly in flavor, what suggest intrinsic characteristics that physical-chemical analysis cannot measure. On the other hand, TM x LP 94 did not have adequate juice yield and total dissolved solids, however, the consumers liked it. This fact confirms how particular 
some perceptions are and how they can't be measured without the human senses. TM x LP 222 and TM x LP 5 were those that were accepted in physical-chemical and sensory parameters, being the most suitable to become new varieties.

Nevertheless, differences between the means do not take into account the individual preference of tasters, assuming they have the same behavior and that the means represent them properly, therefore, for this reason the internal preference mapping was performed with the attributes to visualize the representation of preference directions of the consumers and considering that aroma and overall appearance did not showed major differences in relation to the other attributes, we mapped texture, color and flavor (Felberg et al., 2010).

According to Della-Modesta (1994), the color is a characteristic well recognized by consumer and the first principal component accounted $26.46 \%$, while the second was $18.62 \%$, which together explained $45.08 \%$ of the variance (Figure 1).
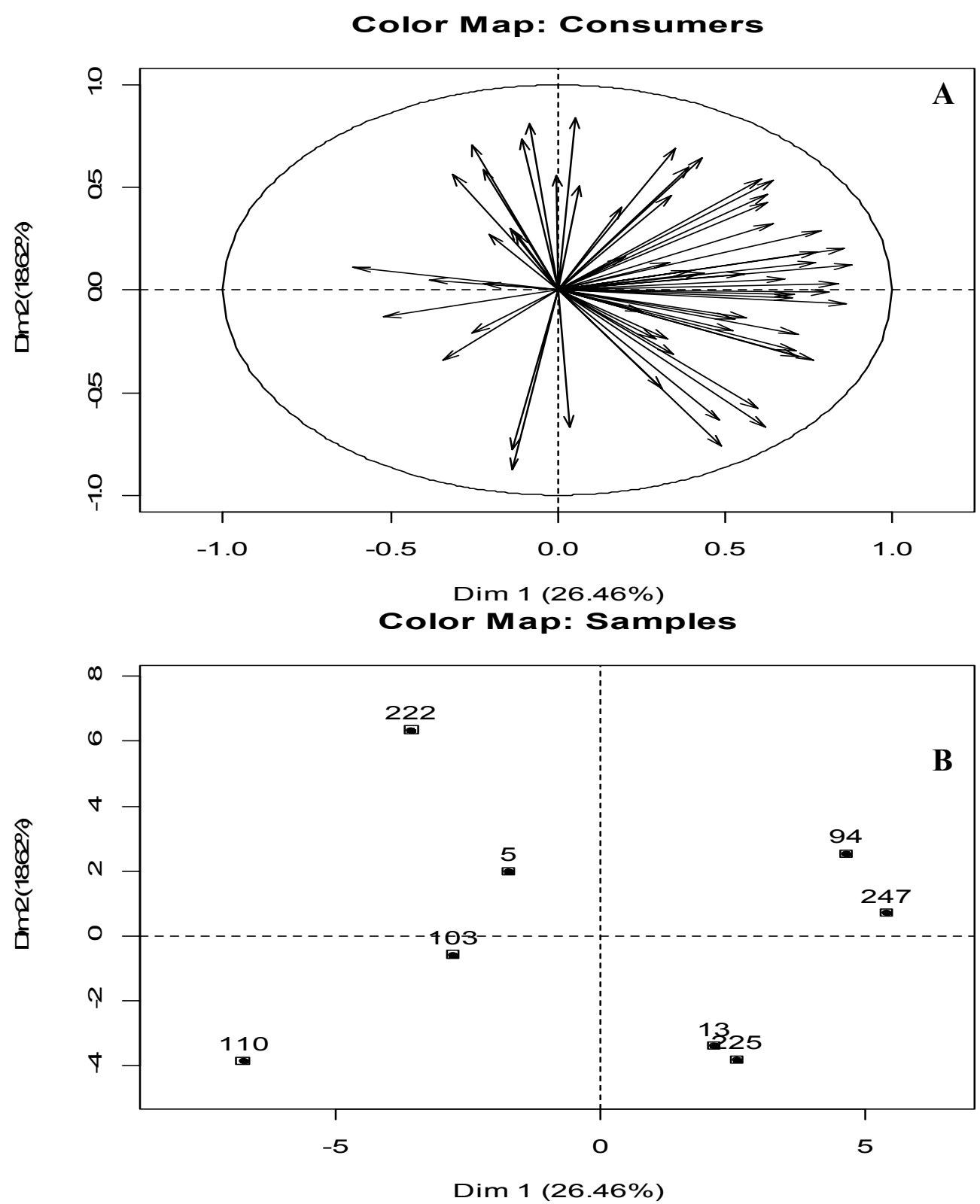

Figure 1. Internal preference map for Juice Color showing: (A) Consumers displayed as variables in a multivariate space and (B) juice samples 
In Figure 1(B), we can observe that TM x LP 225 and TM x LP 13 were represented side by side as well as TM x LP 247 and TM x LP 94, suggesting proximity in color. The majority of consumers were affected positively by the first principal component (Figure 1A)and preferred TM x LP 247, TM x LP 225, TM x LP 94 and TM x LP 13 samples, while the others samples were disliked, but for further considerations, it necessary to analyze texture and flavor.

Figure 2 represents the internal map derived from the juice texture scores, which the first two principal components explained $47.18 \%$ of the variance.

Texture Map: Consumers
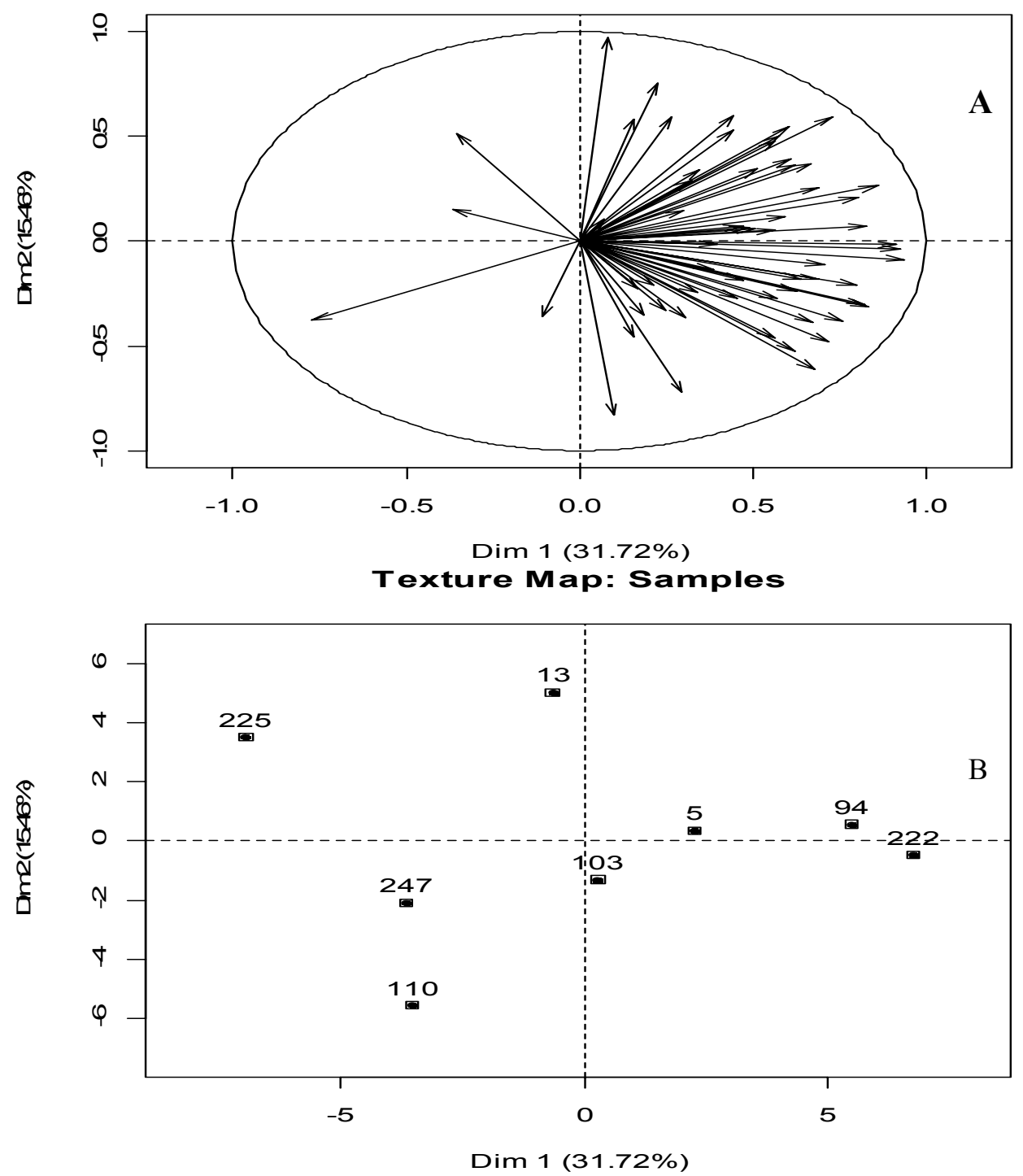

Figure 2. Internal Preference Map for Juice Texture showing: (A) Consumers displayed as variables in a multivariate space and (B) Juice samples

Texture may be described by the sensations given by structural, mechanical and surface of food detected by human senses (Szczesniak, 2002) and, for orange juice, it was described by trained taster in terms of more or less aqueous, viscous, astringency and with grumes (Verruma-Bernardi \& Spoto 2003). The map (Figure 2A) showed consumers totally affected by the first principal component, excluding any link to the TM x LP 13, TM x LP 225, TM x LP 247 and TC x LP 110 samples and preferring TM x LP 222, TM x LP 94 and TC x LP 103 and TC x LP 5 (Figure 2B). These results were not expected since juices were made with the presence of mechanical filters in the 
extractor, which could standardize the samples, but clearly indicated that grumes is not the principal texture characteristic felt by tasters.

Figure 3 shows the internal map for flavor. The first principal component $(52.54 \%)$ and second principal component (11.48\%) amounted $64.02 \%$ of the variance.

\section{Flavor Map: Consumers}
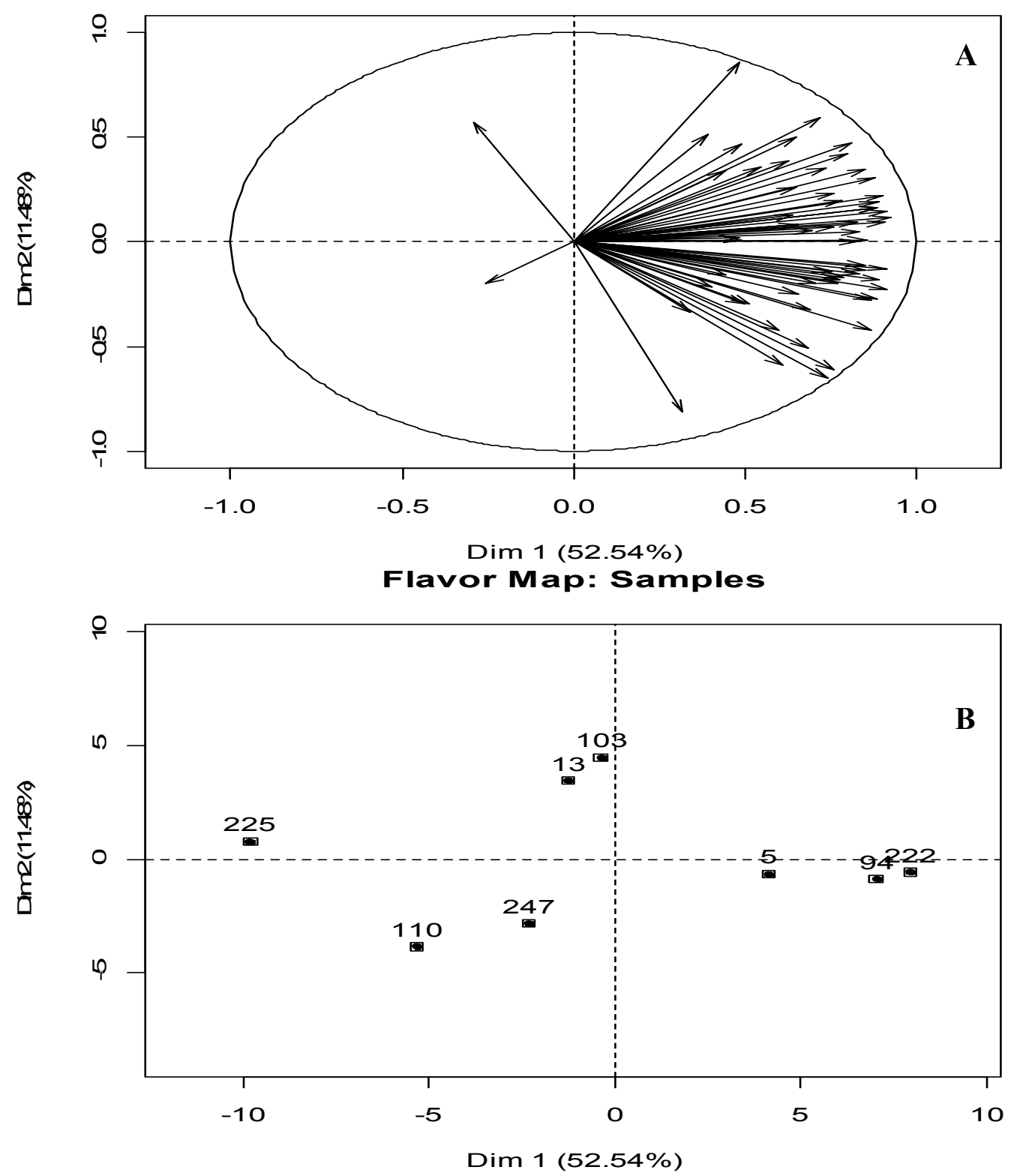

Figure 3. Internal preference map for juice flavor showing: (A) Consumers displayed as variables in a multivariate space and (B) Position of juice samples

The values of principal components features flavor as the sensory attribute more efficient on the explanation of consumers' acceptance, since flavor is the most important component of citrus juices. Five samples were represented into two groups (Figure 3B): TM x LP 222, TM x LP 94 and TC x LP 5; TM x LP 13 and TC x LP 103. Since the samples that present higher ratio and higher quantity of sugar and consequently more sweetness represent also the consumer preference (Sato et al., 2004; Jayasena \& Cameron, 2008), more consumers liked the right samples (Figure 3A) because of the ratio and TDS (Table 1) presented, compared to the left samples. 
Curiously, TM x LP 94 sample did not show the higher values of ratio and TDS, but was accepted while consumers disliked TM x LP 247 with high values of sweetness (Table 1). TM x LP 94 even not being adequate in physical-chemical analysis and fruit appearance, had adequacy in color, aroma, flavor and texture, what could indicate it to a new sensory analysis to be tested in fresh consumption paired with commercial oranges. TM x LP 225 and 13 had inadequacy in flavor, probably because of the inappropriate ratio (Table 1), which itself discard these hybrids to be commercial released. TM x LP 110 and TC x LP 103 were completely not accepted by consumers even though appropriate physical-chemical parameters. This fact confirms intrinsic characteristics not measured by traditional matters as sorts of flavor as sourness, and again reinforces the necessity of the sensory analysis be together with the physical-chemical analysis to complete characterization of fruits.

\section{Conclusion}

The most widely accepted hybrids, TM x LP 222 and TC x LP 5 can be highlighted as ones of the most suitable for the juice industry and potential varieties for fresh fruit market, since it has great consumer preference for flavor and juice yield equal to $52.15 \%$ and $45.1 \%$ respectively. TM x LP 94 got acceptability in color, aroma, flavor and texture and had high approval index, however, was not approved in physical-chemical analysis due to the few juice provided (38.5\%), thus, it should be retested to fresh consumption. The results of sensory analysis features flavor as the principal attribute to discriminate consumers' acceptance to orange juices and finally, as was the goal of this study, the sensory analysis allowed another view of the most adequate fruits to be selected by industry or fresh fruit market released than when only based on physical-chemical parameters, what is for itself a new way of data treatment.

\section{References}

Bastianel, M., Freitas-Astúa, J., Rodrigues, V., Antonioli-Luizon, R., Arrivabem, F., \& Machado, M. A. (2004). Response of 'murcott' tangor to inoculation of citrus leprosis virus under field and greenhouse conditions. Revista Laranja, 25(2), 337-348.

Borgognone, M. G., Bussi, J., \& Hough, G. (2001). Principal component analysis in sensory analysis: covariance or correlation matrix. Food Quality and Preference, 12(5-7), 323-326. http://dx.doi.org/10.1016/S0950-3293(01)00017-9

Brandão, M. C. C., Maia, G. A., Lima, D. P., Parente, E. J. S., Campello, C. C., Nassu, R. T., ... Sousa, P. H. M. (2003). Physical and chemical, microbiological and sensorial analysis of mango fruits submitted to osmotic-solar dehydration. Revista Brasileira de Fruticultura, 25(1), 38-41. http://dx.doi.org/10.1590/S0100-29452003000100012

Cancalon, P. F. (2003). Decrease in Florida citrus acidity over the last fifty years. Florida State Horticultural Society, 116, 379-382.

Cardello, H. M. A. B., \& Faria, J. B. (2000). Acceptance evaluation of sugar cane brandy by sensorial affective tests and internal preference map. Ciência e Tecnologia de Alimentos, 20(1), 32-36. http://dx.doi.org/10.1590/S0101-20612000000100007

Carolyn, F. R. (2009). Sensory science at the human-machine interface. Trends Food Science and Technology, 20(2), 63-72. http://dx.doi.org/10.1016/j.tifs.2008.11.004

CEAGESP. Companhia de Entrepostos e Armazéns Gerais do Estado de São Paulo. (2009). Ficha da laranja Pera. Retrieved July 05, 2011, from http://www.ceagesp.gov.br/hortiescolha/anexos/ficha_laranja_pera.pdf

Couto, M. A. L., \& Canniatti-Brazaca, S. G. (2010). Quantification of vitamin C and antioxidant capacity of citrus $\begin{array}{llllll}\text { varieties. Ciência } \quad \text { e } & \text { Tecnologia de Alimentos, } & 30(1), & 15-19 .\end{array}$ http://dx.doi.org/10.1590/S0101-20612010000500003

Della-Modesta, R. C. (1994). Manual de análise sensorial de alimentos e bebidas. Rio de Janeiro: EMBRAPA-CTAA.

FAO. (Food and Agriculture Organization). (2013). Faostat. Statistical database. Retrieved August 25, 2013, from http://faostat.fao.org/site/567/default.aspx

Felberg, I., Deliza, R., Farah, A., Calado, E., \& Donangelo, C. M. (2010). Formulation of a soy-coffee beverage by response surface methodology and internal preference mapping, Journal Sensory Studies, 25(1), 226-242. http://dx.doi.org/10.1111/j.1745-459X.2010.00278.x 
Figueiredo, M. G., Barros, A. L. M., \& Conceição, J. C. P. R. (2012). Retorno econômico dos investimentos em P\&D na citricultura paulista. Revista de Economia e Sociologia Rural, 50(3), 493-503. http://dx.doi.org/10.1590/S0103-20032012000300006

Griffths, A. J. F., Wessler, S. R., Lewontin, R. C., \& Carrol, S. B. (2008). Introduction to genetic analysis (5th ed., pp. 25-75). Guanabara Koogan, Rio de Janeiro, RJ.

Husson, F., Josse, J., Lê, S., \& Mazet, J. (2007). FactoMineR: Factor analysis and data mining with R. R package version 1.04. Retrieved from http://CRAN.R-project.org/package=FactoMineR

IBGE. (Brazilian Institute of Geography and Statistics). (2011). PAM 2011. Retrieved February 03, 2013, from ftp://ftp.ibge.gov.br/Producao_Agricola/Producao_Agricola_Municipal_[anual]/2011/pam2011_comentario s.pdf

Jayasena, V., \& Cameron, I. (2008). Brix/acid ratio as a predictor of consumer acceptability of crimson seedless table grapes. Journal Food Quality, 31, 736-750.

Kader, A. A. (1999). Fruit maturity, ripening, and quality relationships. Acta Horticultural, 485, 203-208.

Latado, R. R., Tognato, P. C., Stenico-Silva, M. E., Nascimento, L. M., \& Santos, P. C. (2008). Accumulation of anthocyanins and characteristics of fruits of blood oranges during cold storage, Revista Brasileira de Fruticultura, 30(3), 604-610. http://dx.doi.org/10.1590/S0100-29452008000300007

MacFie, H. J. N., Bratchell, N., Greenhoff, K., \& Vallis, L. (1989). Designs to balance the effect of order of presentation and first-order carry-over effects in hall tests. Journal Sensory Study, 4, 129-148.

Machado, M. A., Cristofani-Yaly, M., \& Bastianel, M. (2011). Breeding, genetic and genomic of citrus for disease resistance. Revista Brasileira de Fruticultura, special volume(E), 158-172. http://dx.doi.org/10.1590/S0100-29452011000500019

MAPA (Ministry of Agriculture, Livestock and Food Supply). (2000). Regulamento técnico para fixação dos padrões de identidade e qualidade para suco de laranja. Retrieved July 05, 2011, from http://extranet.agricultura.gov.br/sislegis-consulta/servlet/VisualizarAnexo?id=1637

MAPA (Ministry of Agriculture, Livestock and Food Supply). (2002). Regulamento técnico de identidade e de qualidade para a classificação da tangerina. Retrieved July 05, 2011, from http://extranet.agricultura.gov.br/sislegis-consulta/servlet/VisualizarAnexo?id=15382

Minim, V. P. R. (2006). Análise Sensorial: estudos com consumidores (Chap. 3) (2nd ed., pp. 66-83). UFV, Viçosa, MG.

Neves, M. F., Trombin, V. G., Milan, P., Lopes, F. F., Cressoni, F., \& Kalaki, R. (2010). O retrato da citricultura brasileira. Retrieved January 28, 2013, from http://www.citrusbr.com/download/Retrato_Citricultura_Brasileira_MarcosFava.pdf

Oliveira, R. P., Cristofani, M., Vildoso, C. I. A., \& Machado, M. A. (2002). Genetic diversity among hybrids of 'Cravo' mandarin and 'Pera' sweet Orange. Pesquisa Agropecuária. Brasileira, 34(4), 479-484. http://dx.doi.org/10.1590/S0100-204X2002000400008

Pacheco, C. A., Martelli, I. B., Polydoro, D. A., Schinor, E. H., Pio, R. M., Kupper, K. C., \& Azevedo, F. A. (2012). Resistance and susceptibility of mandarins and their hybrids to Alternaria alternata. Scientia Agricola, 69(6), 386-392. http://dx.doi.org/ 10.1590/S0103-90162012000600007

Pereira, M. E. C., Cantillano, F. F., Gutierrez, A. S. D., \& Almeida, G. V. B. (2006). Procedimentos pós-colheita na produção integrada de citros. Embrapa, Cruz das Almas, BA. Retrieved July 05, 2011, from http://www.cnpmf.embrapa.br/publicacoes/documentos/documento_156.pdf

Pio, R. M., Figueiredo, J. O., Stuchi, E. S., \& Cardoso, S. A. B. (2005). Variedades Copas. In J. D. Mattos Junior, R. M. P. Negri, \& J. J. Pompeu (Eds.), Citros., 1, 37-60. Instituto Agronômico/Fundag, Campinas, SP.

Plotto, A., Margaría, C. A., Goodner, K. L., Goodrich, R., \& Baldwin, E. A. (2004). Odour and flavour thresholds for key aroma components in an orange juice matrix: terpenes and aldehydes, Flavour Fragrance Journal, 19(6), 491-498. http://dx.doi.org/10.1002/ffj.1470

R Development Core Team. (2011). R: A language and environment for statistical computing. R Foundation for Statistical Computing, Vienna, Austria. Retrieved from http://www.R-project.org

Rodas, M. A. B., \& Torre, J. C. M. D. (2008). Sensory Analysis. In O. Zenebon, N. S. Pascuet, \& P. Tiglea (Eds.), Physical-chemical methods for food analysis (4th ed., pp. 279-320). Instituto Adolfo Lutz, São Paulo, SP. 
Rombaldi, C. V., Tibola, C. S., Fachinello, J. C., \& Silva, J. A. (2007). Perception of Rio Grande do Sul consumers about fruit quality questions, Revista Brasileira de Fruticultura, 29(3), 681-684. http://dx.doi.org/10.1590/S0100-29452007000300049

Salibe, A. A., Sobrinho, J. T., \& Müller, G. W. (2002). An overview about Pera sweet orange knowledge. Revista Laranja, 23, 231-245.

SAS. (2003). Statistical Analysis System: version 9.1. SAS Institute, Cary, NC, USA.

Sato, A. C. K., Sanjinez-Argandona, E. J., \& Cunha, R. L. (2004). Physical, chemical and sensorial analysis of industrialized guava in syrup. Ciência e Tecnologia de Alimentos, 24(4), 550-555. http://dx.doi.org/10.1590/S0101-20612004000400012

Souza, P. S., Goes, A., Stuchi, E. S., Jaimes, E. P. G., Wickert, E., Silva, S. R., \& Donadio, L. C. (2006). Reaction of oranges varieties and clones to Xylella fastidiosa. Revista Brasileira de Fruticultura, 28(1), 145-147. http://dx.doi.org/10.1590/S0100-29452006000100040

Steger, E. (1990). Quality and maturation of tangerines and their hybrids in São Paulo. Revista Laranja, 11, 463-502.

Szczesniak, A. S. (2002). Texture is a sensory property. Food Quality Preference, 13(4), 215-225. http://dx.doi.org/10.1016/S0950-3293(01)00039-8

Teixeira, L., Lopes, F. F., \& Neves, M. F. (2004). Young consumer's behavior of orange fruit and juice in state of São Paulo, Brazil. Revista Laranja, 25, 259-275.

Teófilo Sobrinho, J., Müller, G. W., Figueiredo, J. O., Laranjeira, F. F., \& Salibe, A. A. (2001). Pera IAC 2000 sweet orange. Revista Laranja, 22, 495-501.

Verruma-Bernardi, M. R., \& Spoto, M. H. F. (2003). Effect of gamma irradiation on sensory profile of orange $\begin{array}{lllll}\text { juice. Ciência } e \text { Tecnologia de Alimentos, } & \text { 23(1), }\end{array}$ http://dx.doi.org/10.1590/S0101-20612003000100007

Zenebon, O. (2008). Introduction. In O. Zenebon, N. S., Pascuet, \& P. Tiglea (Eds.), Physical-chemical methods for food analysis (4th ed., pp. 9-11). Instituto Adolfo Lutz, São Paulo, SP. 